\title{
PENERAPAN MODEL PEMBELAJARAN KOOPERATIF TIPE TALKING STICK TERHADAP KEMAMPUAN BERFIKIR KREATIF MATEMATIKA SISWA DI SMP NEGERI 11 PADANGSIDIMPUAN
}

\author{
Haritsah Hammamah Harahap dan Agus Makmur Panjaitan \\ Pendidikan Matematika, Universitas Graha Nusantara \\ email: haritsahhammamah@gmail.com
}

\begin{abstract}
This research is a research experiment, with the entire population of students of class VIII SMP Negeri 11 Padangsidimpuan which consists of 3 classes. Sampling in this research is done by using the technique of cluster sample, which of the engineering cluster sample. Data analysis techniques include test normality, test its homogeneity and test hypotheses. Hypothesis testing is carried out by two roads at anava extent confidence $\alpha=0.05$. The results of the analysis on two path with cell anava not same retrieved $F_{-} a=F_{-}$tabel $=$ 18,51 with 1,079. Furthermore the research results obtained from the average of 78.00 experiment class while the average classroom control now and results at 71.96 class experiment 4.15 while 3.48 control class. The descriptive data analysis used in the observation activities of the students and the students answer patterns. Observation results acquired the levels of activity of the students in the class of experiment of $75.81 \%$ with good qualifications while at $67.81 \%$ control classes with qualified enough. As for the pattern of experimental class students answer better than the class of the control. Based on the research results, it is recommended to apply the cooperative learning model type of the talking stick.
\end{abstract}

Keywords: the talking stick, creative thinking, research experiment

\begin{abstract}
Abstrak
Penelitian ini merupakan penelitian eksperimen, dengan populasi seluruh siswa kelas VIII SMP Negeri 11 Padangsidimpuan yang terdiri dari 3 kelas. Pengambilan sampel dalam penelitian ini dilakukan dengan menggunakan teknik cluster sample, yang mana dari teknik cluster sample. Teknik analisis data meliputi uji normalitas, uji homogenitas dan uji hipotesis. Pengujian hipotesis dilakukan dengan anava dua jalan pada taraf kepercayaan $\alpha=0,05$. Hasil analisis pada anava dua jalan dengan sel tak sama diperoleh $F_{a}=1,079$ dengan $F_{\text {tabel }}=18,51$. Selanjutnya dari hasil penelitian diperoleh rata-rata kelas eksperimen 78,00 sedangkan rata-rata kelas kontrol 71,96 dan hasil angket pada kelas eksperimen 4,15 sedangkan kelas kontrol 3,48. Analisis data secara deskriptif digunakan pada observasi aktivitas siswa dan pola jawaban siswa. Hasil observasi diperoleh kadar aktivitas siswa pada kelas eksperimen 75,81\% dengan kualifikasi baik sedangkan pada kelas kontrol 67,81\% dengan kualifikasi cukup. Adapun pola jawaban siswa kelas eksperimen lebih baik daripada kelas kontrol. Berdasarkan hasil penelitian, disarankan untuk menerapkan model pembelajaran kooperatif tipe talking stick.
\end{abstract}

Kata Kunci: talking stick, berfikir kreatif, penelitian eksperimen

\section{PENDAHULUAN}

Kegiatan pembelajaran melibatkan dua orang pelaku, yaitu guru dan siswa. Dimana guru mengajar dan siswa belajar. Kegiatan pembelajaran dirancang dengan 

berpusat pada siswa untuk mendorong motivasi, minat, kreativitas dan semangat belajar pada diri siswa. Oleh karena itu proses pembelajaran perlu direncanakan, dilaksanakan, dinilai, dan diawasi agar terlaksana secara efektif dan efisien. Proses pembelajaran hendaknya dapat mendorong munculnya kemampuan berfikir kreatif siswa khususnya dalam mata pelajaran matematika (Slavin, 2005). Menurut Mahmudi (2010) salah satu yang dapat menunjang dan mendorong siswa dalam mengembangkan kemampuan berfikir kreatif matematika adalah kesiapan siswa dalam menerima pelajaran matematika.

Seorang guru hendaknya memiliki strategi agar tujuan pembelajaran dapat dicapai secara efektif dan efisien. Menurut Rusman (2012) strategi adalah suatu kegiatan pembelajaran yang harus dikerjakan guru dan siswa agar tujuan pembelajaran dapat dicapai secara efektif dan efisien Strategi pembelajaran merupakan cara-cara yang dipilih untuk menyampaikan materi pembelajaran dalam lingkungan pembelajaran tertentu yang dapat memberikan pengalaman belajar kepada peserta didik. Menurut Ngalimun (2012) dengan adanya pemilihan strategi yang tepat, misalnya dalam pemilihan model atau metode yang akan digunakan di dalam aktivitas belajar hendaknya strategi yang digunakan tersebut memudahkan peserta didik dalam menerima dan memahami materi yang diajarkan sehingga tujuan dari pembelajaran itu dapat dicapai.

Berdasarkan hasil wawancara yang dilakukan peneliti dengan guru matematika di SMP Negeri 11 Padangsidimpuan menyatakan bahwa salah satu kendala utama di dalam proses pembelajaran adalah kurangnya antusias siswa untuk belajar. Salah satu kelemahan siswa sehingga sulit memahami pelajaran matematika adalah siswa tidak mengulang kembali dirumah materi yang telah diajarkan sehingga hal ini menyebabkan kurangnya kesiapan siswa dalam menerima pelajaran dan menyebabkan kurangnya kemampuan berpikir kreatif siswa dalam memecahkan masalah matematika. Dari hasil tes yang diberikan, hanya 43,5\% siswa yang mampu menyelesaikan masalah matematika terutama dalam mengubah soal cerita kedalam bentuk matematika dan menyelesaikannya.

Dengan melihat permasalahan di atas, maka perlu di upayakan suatu model pembelajaran kooperatif yang dapat membantu siswa dalam memecahkan masalah matematika berupa soal cerita. Kemudian model pembelajaran kooperatif yang dipilih diharapkan dapat melatih kesiapan siswa di dalam menerima pelajaran sehingga siswa aktif dan mendorong siswa agar memiliki kemampuan berpikir kreatif dalam proses pembelajaran matematika.

Menurut Istarani (2011:89) talking stick adalah suatu model pembelajaran yang mendorong siswa untuk berani mengemukakan pendapat. Model pembelajaran kooperatif ini diharapkan dapat mendorong siswa untuk siap dalam menerima pelajaran matematika karena siswa dituntut untuk siap menjawab pertanyaan yang diberikan guru. Model pembelajaran kooperatif ini juga dapat membantu mengatasi masalah kurangnya kesiapan siswa dalam menerima pelajaran dan mampu meningkatkan minat dan motivasi serta kreativitas siswa karena dengan adanya bantuan tongkat yang dapat menjadi pengikat daya tarik siswa di dalam mengikuti mata pelajaran matematika.

\section{METODE PENELITIAN}

Jenis penelitian yang digunakan adalah true eksperimen. True experimental design yaitu jenis eksperimen yang dianggap sudah baik karena memenuhi persyaratan. Rancangan yang digunakan dalam penelitian ini adalah rancangan 
faktorial $2 \times 3$. Rancangan dalam penelitian ini dapat digambarkan seperti pada tabel 1 .

Tabel 1. Rancangan Penelitian

\begin{tabular}{|c|c|c|c|c|}
\hline $\mathrm{A}$ & $\mathrm{B}$ & $b_{1}$ & $b_{2}$ & $b_{3}$ \\
\hline$a_{1}$ & $a_{1}, b_{1}$ & $a_{1}, b_{2}$ & $a_{1}, b_{3}$ \\
\hline$a_{2}$ & $a_{2}, b_{1}$ & $a_{2}, b_{2}$ & $a_{2}, b_{3}$ \\
\hline
\end{tabular}

Keterangan:

$A=$ Model Pembelajaran

$a_{1}=$ Model Pembelajaran kooperatif tipe talking stick.

$a_{2}=$ Model Pengajaran Langsung.

$B=$ Kemampuan berfikir kreatif matematika siswa.

$b_{1}=$ Kemampuan berfikir kreatif matematika siswa tinggi.

$b_{2}=$ Kemampuan berfikir kreatif matematika siswa sedang.

$b_{3}=$ Kemampuan berfikir kreatif matematika siswa rendah.

Prosedur penelitian adalah tahap-tahap kegiatan dengan seperangkat alat pengumpulan data dan seperangkat pembelajaran. Tahap tersebut adalah sebagai berikut:

1. Tahap Persiapan

Pada tahap ini persiapan kegiatan yang dilakukan adalah:

- Menyusun jadwal penelitian disesuaikan dengan jadwal yang ada di sekolah.

- Menyusun rancangan pembelajaran dengan model pembelajaran kooperatif tipe talking stick dan model pengajaran langsung.

- Menyiapkan alat pengumpulan data berupa tes kemampuan berpikir kreatif, angket, dan observasi.

- Melakukan validasi instrumen tes.

2. Tahap Pelaksanaan

Dalam penelitian ini tahap pelaksanaan dilakukan sebagai berikut:

- Menentukan dua kelompok subjek penelitian yang diambil dari populasi dengan tehnik cluster sampling, kelas eksperimen diterapkan dengan model pembelajaran kooperatif tipe talking stick dan kelas kontrol dengan model pengajaran langsung.

- Setelah memperoleh dua kelas yang digunakan dalam penelitian, kemudian dilakukan pretes pada kelas eksperimen dan kelas kontrol.

- Melaksanakan pembelajaran pada kelas eksperimen dan kelas kontrol sesuai dengan perlakuan masing-masing. Kemudian mengamati (observasi) siswa selama proses pembelajaran berlangsung.

- Memberikan postes kepada kedua kelompok. Tes ini diberikan setelah perlakuan selesai, kemudian menghitung rata-rata perolehan masing-masing kelompok. Kemudian diberikan angket berfikir kreatif.

3. Tahap Akhir

Tahap akhir dalam penelitian ini meliputi:

- Menganalisis data hasil perolehan pretes dan postes.

- Menganalisis data hasil observasi.

- Menganalisis data hasil angket.

- Menarik kesimpulan dari hasil perolehan data penelitian. 


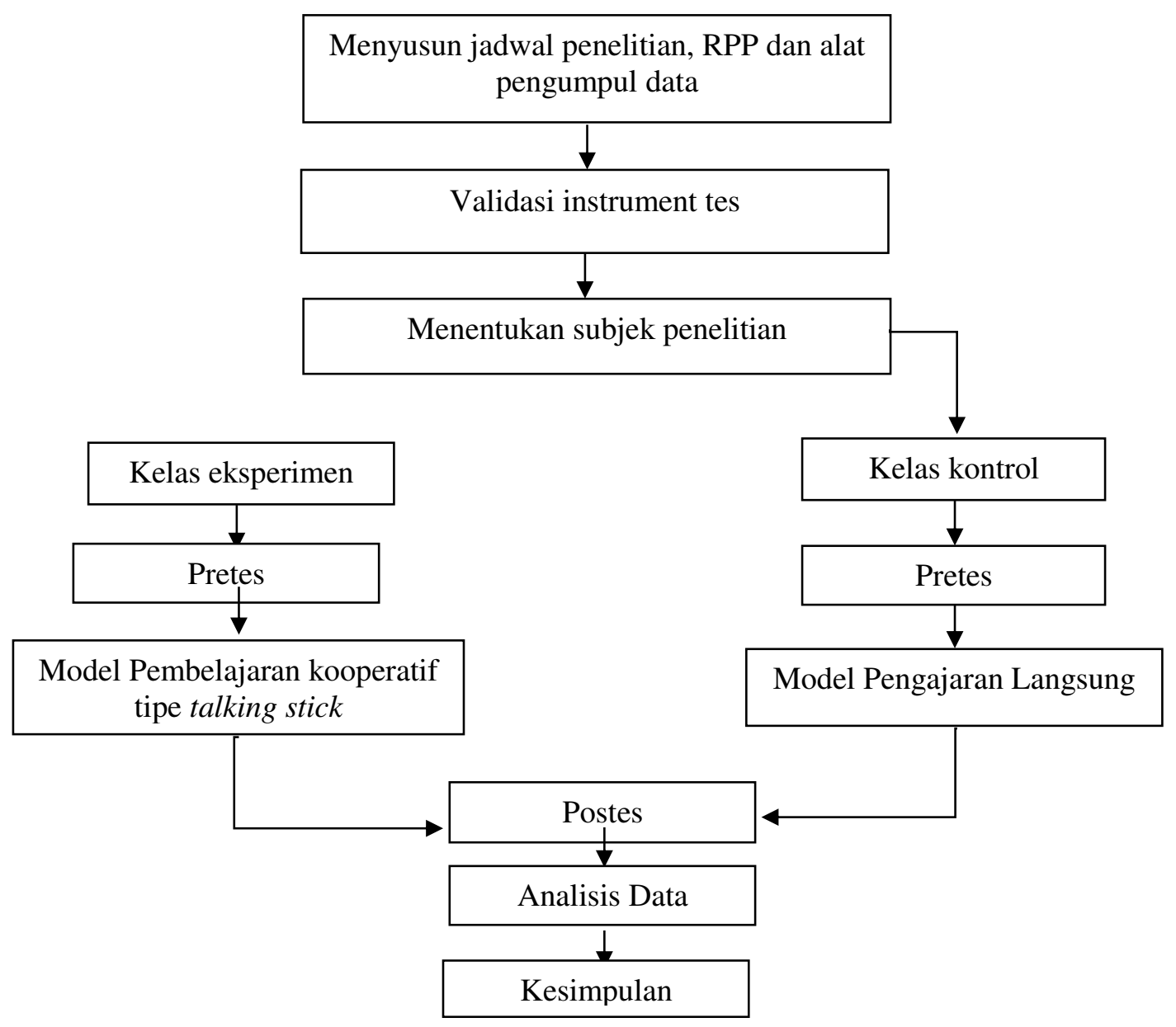

Gambar 1. Skema Prosedur Penelitian

\section{HASIL DAN PEMBAHASAN}

Berdasarkan data hasil pretes dan postes yang diperoleh siswa tentang kemampuan berfikir kreatif matematika dikelas eksperimen dan kelas kontrol dapat dilihat adanya perbedaan kemampuan berfikir kreatif matematika siswa yang diajarkan melalui model pengajaran langsung dengan model pembelajaran kooperatif tipe talking stick. Untuk lebih jelasnya nilai pretes dan postes disajikan pada gambar 2.

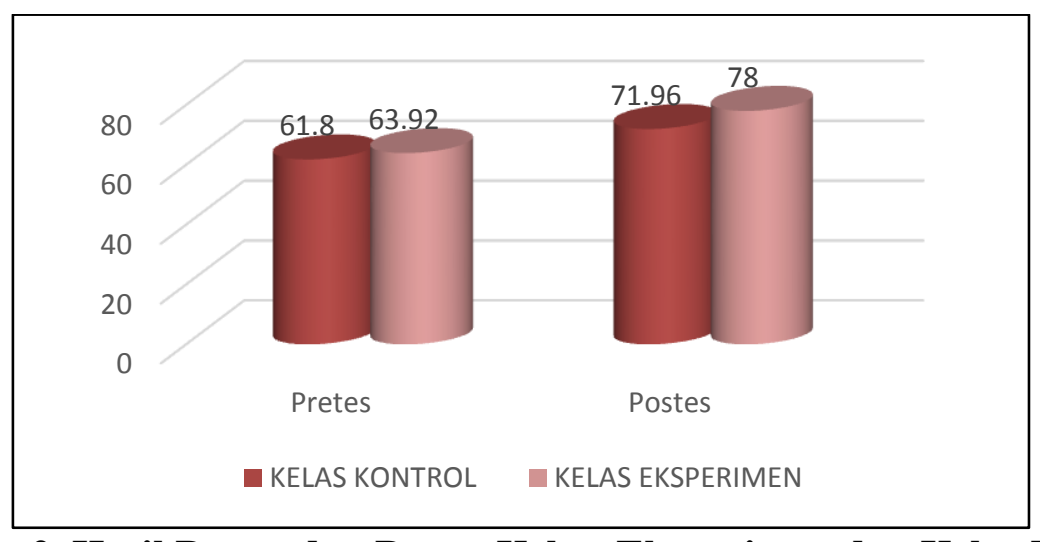

Gambar 2. Hasil Pretes dan Postes Kelas Eksperimen dan Kelas Kontrol 
Uji normalitas data bertujuan untuk menguji normal tidaknya suatu sampel. Untuk menguji normalitas data pretes kelas eksperimen dan kelas kontrol menggunakan tehnik chi-kuadrat dengan bantuan Microsotf Excel 2007 terlihat pada Tabel 2.

Tabel 2. Hasil Uji Normalitas Data pre-test Kelas Eksperimen

\begin{tabular}{|c|c|c|c|c|c|c|c|}
\hline $\begin{array}{c}\text { Kelas } \\
\text { Interval }\end{array}$ & $\begin{array}{c}\text { Batas } \\
\text { Kelas }\end{array}$ & $z$-score & $\begin{array}{c}\text { Batas } \\
\text { Luas } \\
\text { Daerah }\end{array}$ & $\begin{array}{c}\text { Luas } \\
\text { Daerah }\end{array}$ & $\boldsymbol{f}_{\mathbf{0}}$ & $\boldsymbol{f}_{\boldsymbol{h}}$ & $\frac{\left(\boldsymbol{f}_{\mathbf{0}}-\boldsymbol{f}_{\boldsymbol{h}}\right)^{\mathbf{2}}}{\boldsymbol{f}_{\boldsymbol{h}}}$ \\
\hline & 43,5 & $-1,77$ & 0,0384 & & & & \\
\hline $44-50$ & & & & 0,0887 & 3 & 2,31 & 0,206 \\
\hline & 50,5 & $-1,14$ & 0,1271 & & & & \\
\hline $51-57$ & & & & 0,1779 & 7 & 4,63 & 1,213 \\
\hline & 57,5 & $-0,51$ & 0,3050 & & & & \\
\hline $58-64$ & & & & 0,2428 & 6 & 6,31 & 0,015 \\
\hline & 64,5 & 0,12 & 0,5478 & & & & \\
\hline $65-71$ & & & & 0,2256 & 2 & 5,87 & 2,551 \\
\hline & 71,5 & 0,75 & 0,7734 & & & & \\
\hline $72-78$ & & & & 0,1428 & 5 & 3,71 & 0,449 \\
\hline & 78,5 & 1,38 & 0,9162 & & & & \\
\hline $79-85$ & & & & 0,0616 & 3 & 1,60 & 1,225 \\
\hline & 85,5 & 2,01 & 0,9778 & & & & \\
\hline
\end{tabular}

Dari tabel 2 diperoleh nilai chi-kuadrat hitung $\left(X^{2}\right.$ hitung $)=5,659$. Dengan $n=6, d k=n-1$, sehingga $d k=6-1=5$ dan taraf signifikan $\alpha=0,05$ didapat $X^{2}$ tabel $=11,070$. Selanjutnya membandingkan $X^{2}$ hitung dengan $X^{2}$ tabel ternyata $X^{2}$ hitung $<X^{2}$ tabel maka dapat disimpulkan bahwa data nilai pre-test kemampuan berfikir kreatif pada kelas eksperimen berdistribusi normal Tabel 3.

Dari perhitungan pada tabel 2 diperoleh nilai Chi-kuadrat hitung $\left(X^{2}\right.$ hitung $)=3,351$. Dengan $n=6, d k=n-1$, sehingga $d k=6-1=5$ dan taraf signifikan $\alpha=0,05$ didapat $X^{2}$ tabel $=11,070$. Selanjutnya membandingkan $X^{2}$ hitung dengan $X^{2}$ tabel ternyata $X^{2}$ hitung $<X^{2}$ tabel maka dapat disimpulkan bahwa data nilai pre-test kemampuan berfikir kreatif pada kelas kontrol berdistribusi normal.

Tabel 3. Hasil Uji Normalitas Data pre-test Kelas Kontrol

\begin{tabular}{|c|c|c|c|c|c|c|c|}
\hline $\begin{array}{c}\text { Kelas } \\
\text { Interval }\end{array}$ & $\begin{array}{c}\text { Batas } \\
\text { Kelas }\end{array}$ & $z$-score & $\begin{array}{c}\text { Batas } \\
\text { Luas } \\
\text { Daerah }\end{array}$ & $\begin{array}{c}\text { Luas } \\
\text { Daerah }\end{array}$ & $\boldsymbol{f}_{\mathbf{0}}$ & $\boldsymbol{f}_{\boldsymbol{h}}$ & $\frac{\left(\boldsymbol{f}_{\mathbf{0}}-\boldsymbol{f}_{\boldsymbol{h}}\right)^{\mathbf{2}}}{\boldsymbol{f}_{\boldsymbol{h}}}$ \\
\hline & 36,5 & $-2,30$ & 0,0107 & & & & \\
\hline $37-44$ & & & & 0,0499 & 1 & 1,25 & 0,050 \\
\hline & 44,5 & $-1,55$ & 0,0606 & & & & \\
\hline $45-52$ & & & & 0,1513 & 4 & 3,78 & 0,013 \\
\hline & 52,5 & $-0,80$ & 0,2119 & & & & \\
\hline $53-60$ & & & & 0,2682 & 9 & 6,71 & 0,782 \\
\hline & 60,5 & $-0,05$ & 0,4801 & & & & \\
\hline $61-68$ & & & & 0,2810 & 5 & 7,03 & 0,586 \\
\hline & 68,5 & 0,71 & 0,7611 & & & & \\
\hline $69-76$ & & & & 0,1667 & 3 & 4,17 & 0,328 \\
\hline & 76,5 & 1,46 & 0,9278 & & & & \\
\hline $77-84$ & & & & 0,0586 & 3 & 1,47 & 1,592 \\
\hline & 84,5 & 2,21 & 0,9864 & & & & 3,351 \\
\hline
\end{tabular}


Untuk menguji normalitas data postes kelas eksperimen dan kelas kontrol menggunakan tehnik chi-kuadrat dengan bantuan Microsotf Excel 2007 terlihat pada Tabel 4.

Tabel 4. Hasil Uji Normalitas Data pos-test Kelas Eksperimen

\begin{tabular}{|c|c|c|c|c|c|c|c|}
\hline $\begin{array}{c}\text { Kelas } \\
\text { Interval }\end{array}$ & $\begin{array}{c}\text { Batas } \\
\text { Kelas }\end{array}$ & $\boldsymbol{z}$-score & $\begin{array}{c}\text { Batas } \\
\text { Luas } \\
\text { Daerah }\end{array}$ & $\begin{array}{c}\text { Luas } \\
\text { Daerah }\end{array}$ & $\boldsymbol{f}_{\mathbf{0}}$ & $\boldsymbol{f}_{\boldsymbol{h}}$ & $\frac{\left(\boldsymbol{f}_{\mathbf{0}}-\boldsymbol{f}_{\boldsymbol{h}}\right)^{\mathbf{2}}}{\boldsymbol{f}_{\boldsymbol{h}}}$ \\
\hline & 55,5 & $-2,11$ & 0,0174 & & & & \\
\hline $56-62$ & & & & 0,0561 & 3 & 1,46 & 1,624 \\
\hline & 62,5 & $-1,45$ & 0,0735 & & & & \\
\hline $63-69$ & & & & 0,1384 & 3 & 3,60 & 0,100 \\
\hline & 69,5 & -0.80 & 0,2119 & & & & \\
\hline $70-76$ & & & & 0,2324 & 5 & 6,04 & 0,179 \\
\hline $77-83$ & 76,5 & $-0,14$ & 0,4443 & & & & \\
\hline & & & & 0,2507 & 7 & 6,52 & 0,035 \\
\hline $84-90$ & & 0,51 & 0,6950 & & & & \\
\hline & 90,5 & 1,17 & 0,8790 & & & & \\
\hline $91-97$ & & & & 0,0866 & 4 & 2,25 & 1,361 \\
\hline & 97,5 & 1,82 & 0,9656 & & & & \\
\hline
\end{tabular}

Dari perhitungan pada tabel 4. diperoleh nilai Chi kuadrat hitung $\left(X^{2}\right.$ hitung $)=3,426$. Dengan $n=6, d k=n-1$, sehingga $d k=6-1=5$ dan taraf signifikan $\alpha=0,05$ didapat $X^{2}$ tabel $=11,070$. Selanjutnya membandingkan $X^{2}$ hitung dengan $X^{2}$ tabel ternyata $X^{2}$ hitung $<X^{2}$ tabel maka dapat disimpulkan bahwa data nilai pos-test kemampuan berfikir kreatif pada kelas eksperimen berdistribusi normal Tabel 5 .

Pada tabel 4 juga diperoleh nilai Chi kuadrat hitung $\left(X^{2}\right.$ hitung $)=6,606$. Dengan $n=6, d k=n-1$, sehingga $d k=6-1=5$ dan taraf signifikan $\alpha=0,05$ didapat $X^{2}$ tabel $=11,070$. Selanjutnya membandingkan $X^{2}$ hitung dengan $X^{2}$ tabel ternyata $X^{2}$ hitung $<X^{2}$ tabel maka dapat disimpulkan bahwa data nilai pos-test kemampuan berfikir kreatif pada kelas kontrol berdistribusi normal

Tabel 5. Hasil Uji Normalitas Data pos-test Kelas Kontrol

\begin{tabular}{|c|c|c|c|c|c|c|c|}
\hline $\begin{array}{c}\text { Kelas } \\
\text { Interval }\end{array}$ & $\begin{array}{c}\text { Batas } \\
\text { Kelas }\end{array}$ & $\boldsymbol{z}$-score & $\begin{array}{c}\text { Batas } \\
\text { Luas } \\
\text { Daerah }\end{array}$ & $\begin{array}{c}\text { Luas } \\
\text { Daerah }\end{array}$ & $\boldsymbol{f}_{\mathbf{0}}$ & $\boldsymbol{f}_{\boldsymbol{h}}$ & $\frac{\left(\boldsymbol{f}_{\mathbf{0}}-\boldsymbol{f}_{\boldsymbol{h}}\right)^{\mathbf{2}}}{\boldsymbol{f}_{\boldsymbol{h}}}$ \\
\hline & 53,5 & $-2,70$ & 0,0035 & & & & \\
\hline $54-59$ & & & & 0,0294 & 2 & 0,74 & 2,145 \\
\hline & 59,5 & $-1,84$ & 0,0329 & & & & \\
\hline $60-65$ & & & & 0,1306 & 0 & 3,27 & 3,270 \\
\hline & 65,5 & $-0,98$ & 0,1635 & & & & \\
\hline $66-71$ & & & & 0,2927 & 10 & 7,32 & 0,981 \\
\hline & 71,5 & $-0,12$ & 0,4562 & & & & \\
\hline $72-77$ & & & & 0,3142 & 7 & 7,86 & 0,094 \\
\hline & 77,5 & 0,74 & 0,7704 & & & & \\
\hline $78-83$ & & & & 0,1748 & 5 & 4,37 & 0,091 \\
\hline & 83,5 & 1,60 & 0,9452 & & & & \\
\hline $84-89$ & & & & 0,0466 & 1 & 1,17 & 0,025 \\
\hline & 89,5 & 2,46 & 0,9918 & & & & 6,606 \\
\hline
\end{tabular}


Analisis berikutnya adalah dengan melakukan uji homogenitas kelas eksperimen dan kelas kontrol. Hasil perhitungan untuk uji homogenitas dengan menggunakan Microsoft Excel 2007 dapat dilihat Tabel 6.

Tabel 6. Uji Homogenitas data pre-test Kelas Eksperimen dan Kontrol

\begin{tabular}{|c|c|c|}
\hline \multicolumn{3}{|c|}{ F-Test Two-Sample for Variances } \\
\hline \multicolumn{3}{|c|}{ Data Pre-Test Kemampuan Berfikir Kreatif Matematika } \\
\hline & Eksperimen & Kontrol \\
\hline Mean & 63,92307692 & 61,8 \\
\hline Variance & 134,7138462 & 130,9166667 \\
\hline Observations & 26 & 25 \\
\hline df & 25 & 24 \\
\hline $\mathrm{F}$ & \multicolumn{2}{|c|}{1,029004554} \\
\hline$P(F<=f)$ one-tail & \multicolumn{2}{|c|}{0,473189278} \\
\hline F Critical one-tail & \multicolumn{2}{|c|}{1,974959395} \\
\hline Keterangan & \multicolumn{2}{|c|}{$\begin{array}{c}F_{\text {hitung }}<F_{\text {tabel }} \\
\text { Artinya kedua varians homogen }\end{array}$} \\
\hline
\end{tabular}

Pada tabel 6, diketahui $F_{\text {hitung }}=1,029$ dengan $\mathrm{dk}_{1}=\mathrm{n}_{1}-1$ dan $d k_{2}=$ $n_{2}-1$ pada taraf kepercayaan $\alpha=0,05$ maka dari hasil tersebut diperoleh $F_{\text {tabel }}$ $=1,975$. Dimana $F_{\text {hitung }}<F_{\text {tabel }}$, sehingga dapat diasumsikan bahwa data pretes kelas eksperimen dan kelas kontrol berasal dari populasi dengan varians yang sama atau homogen. Hasil perhitungan untuk uji homogenitas data postes dengan menggunakan Microsoft Excel 2007 dapat dilihat Tabel 7.

Pada tabel 7 diketahui $F_{\text {hitung }}=1,920$, dengan $\mathrm{dk}_{1}=\mathrm{n}_{1}-1$ dan $d k_{2}=$ $n_{2}-1$ pada taraf kepercayaan $\alpha=0,05$ maka dari hasil tersebut diperoleh $F_{\text {tabel }}=$ 1,975. Dimana $F_{\text {hitung }}<F_{\text {tabel }}$, sehingga dapat diasumsikan bahwa data postes kelas eksperimen dan kelas kontrol berasal dari populasi dengan varians yang sama atau homogen.

Tabel 7. Hasil Uji Homogenitas Data pos-test

\begin{tabular}{|c|c|c|}
\hline \multicolumn{3}{|c|}{ F-Test Two-Sample for Variances } \\
\hline \multicolumn{3}{|c|}{ Data Pos-Test Kemampuan Berfikir Kreatif Matematika } \\
\hline & Eksperimen & Kontrol \\
\hline Mean & 78 & 71,96 \\
\hline Variance & 126,48 & 65,87333333 \\
\hline Observations & 26 & 25 \\
\hline df & 25 & 24 \\
\hline $\mathrm{F}$ & \multicolumn{2}{|c|}{1,920048578} \\
\hline $\mathrm{P}(\mathrm{F}<=\mathrm{f})$ one-tail & \multicolumn{2}{|c|}{0,057293975} \\
\hline F Critical one-tail & \multicolumn{2}{|c|}{1,974959395} \\
\hline Keterangan & \multicolumn{2}{|c|}{$\begin{array}{c}F_{\text {hitung }}<F_{\text {tabel }} \\
\text { Artinya kedua varians homogen }\end{array}$} \\
\hline
\end{tabular}

\section{Uji Hipotesis}

Ho: Kemampuan berfikir kreatif matematika siswa yang diajarkan dengan penerapan model pembelajaran kooperatif tipe talking stick lebih baik dibandingkan 
dengan model pengajaran langsung pada materi pokok balok di kelas VIII SMP Negeri 11 Padangsidimpuan.

Ha: Kemampuan berfikir kreatif matematika siswa yang diajarkan dengan penerapan model pembelajaran kooperatif tipe talking stick tidak lebih baik dibandingkan dengan model pengajaran langsung pada materi pokok balok di kelas VIII SMP Negeri 11 Padangsidimpuan.

Dari hasil postes pada kelas eksperimen disimpulkan bahwa siswa yang termasuk dalam kelompok tinggi memiliki skor $>83,625$, kelompok sedang $=72,375 \leq$ skor $\leq 83,625$ dan kelompok rendah $<72,375$. Sedangkan pada kelas kontrol, siswa yang termasuk dalam kelompok tinggi memiliki skor $>76,02$ kelompok sedang $=67,90 \leq$ skor $\leq 76,02$ dan kelompok rendah $<67,90$.

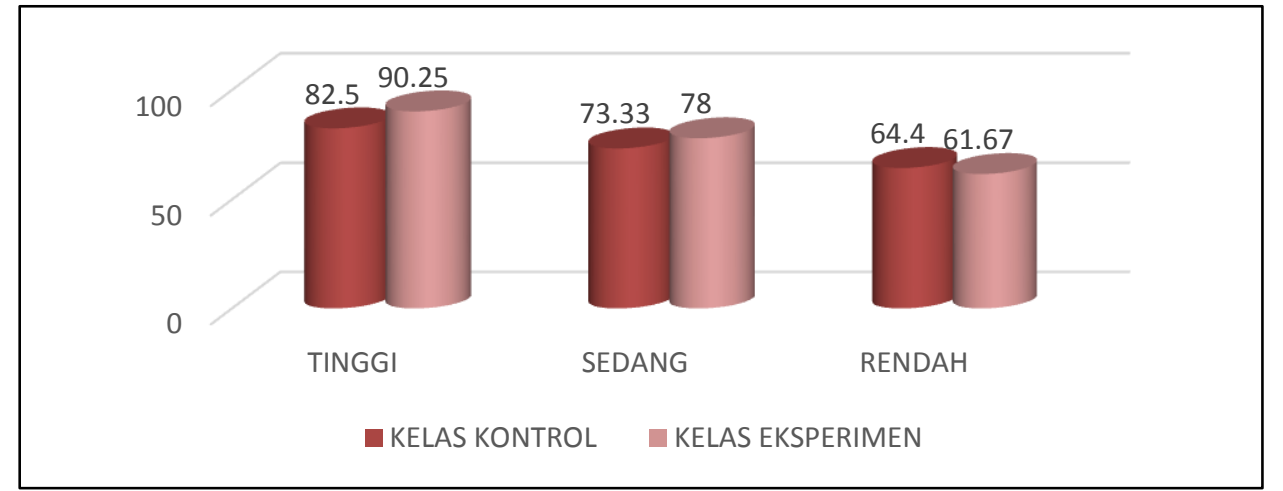

Gambar 3. Grafik Data Hasil Kemampuan Berpikir Kreatif Matematika Siswa

Berdasarkan gambar 3., pada kelas eksperimen yang menggunakan model pembelajaran talking stick terlihat siswa dengan tingkat kemampuan berpikir kreatif matematika tinggi sebanyak 8 orang dengan rata-rata 90,25. Selanjutnya untuk siswa dengan kemampuan berpikir kreatif matematika sedang sebanyak 12 orang dan ratarata 78,00 sedangkan untuk siswa dengan kemampuan berpikir kreatif matematika rendah sebanyak 6 orang dengan rata-rata 61,67.

Pada kelas kontrol dengan menggunakan model pengajaran bukan kooperatif tipe talking stick lebih diperoleh sebanyak 6 orang dengan kemampuan berpikir kreatif matematika tinggi dengan nilai rata-rata 82,50. Untuk siswa dengan tingkat kemampuan berpikir kreatif matematika sedang sebanyak 9 orang dengan nilai ratarata 73,33 sedangkan untuk siswa dengan kemampuan berpikir kreatif matematika rendah sebanyak 10 orang dengan rata-rata sebesar 64,40. Untuk hasil yang lebih jelas dapat dilihat pada gambar 4.

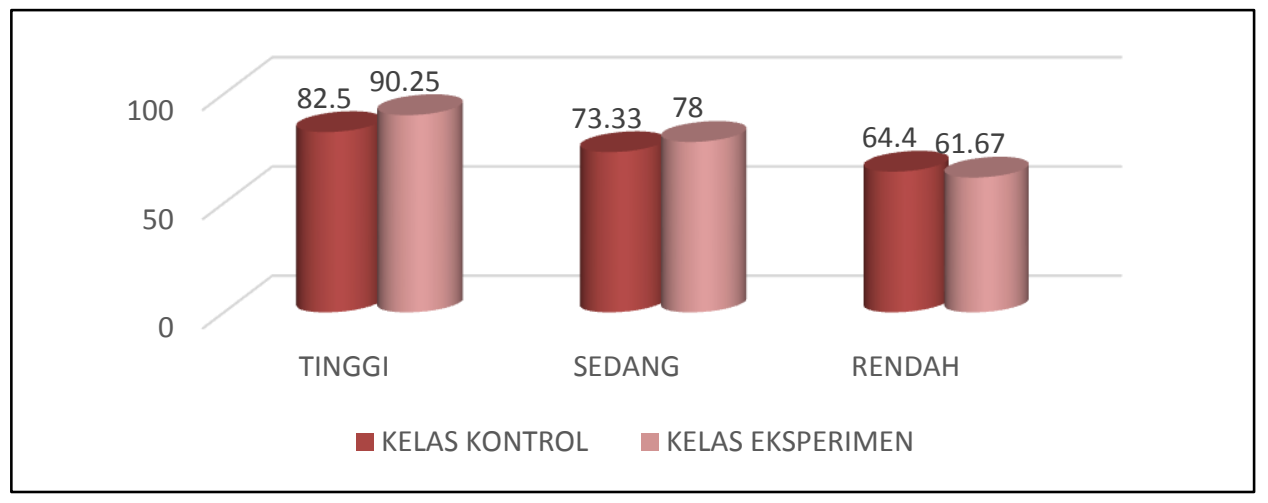

Gambar 4. Grafik Data Hasil Kemampuan Berpikir Kreatif Matematika Siswa 
Dari data hasil kemampuan berfikir kreatif matematika siswa kelas eksperimen dan kontrol, hasil dari analisis data variansi dua jalan dapat dilihat pada tabel 8 .

Tabel 8. Rangkuman Analisis Varians

\begin{tabular}{|l|l|c|c|c|c|}
\hline \multicolumn{1}{|c|}{ Sumber Varians } & \multicolumn{1}{|c|}{ JK } & Dk & KT & F hitung & F tabel \\
\hline Model pembelajaran & $J K A=15,65$ & $d k A=1$ & $K T A=15,65$ & 1,079 & 18,51 \\
\hline $\begin{array}{l}\text { Kemampuan Berfikir } \\
\text { Kreatif Matematika }\end{array}$ & $J K B=545,986$ & $d k B=2$ & $K T B=272,993$ & 18,819 & 19,00 \\
\hline Galat & $J K G=29,012$ & $d k G=2$ & $K T G=14,506$ & & \\
\hline Total & $J K T=590,648$ & $d k T=5$ & & & \\
\hline
\end{tabular}

Untuk mengetahui keputusan uji, maka dilihat harga $\mathrm{F}_{\text {hitung }}$ dan $\mathrm{F}_{\text {tabel }}$. Jika $\mathrm{F}_{\text {hitung }}>\mathrm{F}_{\text {tabel }}$ maka $\mathrm{H}_{0}$ ditolak dan sebaliknya jika $\mathrm{F}_{\text {hitung }}<\mathrm{F}_{\text {tabel }}$ maka $\mathrm{H}_{0}$ diterima. Dari analisis variansi dua jalan dengan sel tak sama pada tabel di atas diperoleh nilai uji $\mathrm{F}_{\mathrm{a}}=\mathrm{F}_{\text {hitung }}=1,079$ dengan nilai $\mathrm{F}_{\text {tabel }}=18,513$.

Dengan demikian $h_{0}$ diterima. Maka disimpulkan bahwa kemampuan berfikir kreatif matematika siswa yang diajarkan dengan penerapan model pembelajaran kooperatif tipe talking stick lebih baik dibandingkan dengan model pengajaran langsung pada materi pokok balok di kelas VIII SMP Negeri 11 Padangsidimpuan.

\section{KESIMPULAN}

Berdasarkan hasil analisis data dapat disimpulkan kemampuan berfikir kreatif matematika siswa yang diajarkan dengan penerapan model pembelajaran kooperatif tipe talking stick lebih baik dibandingkan dengan model pengajaran langsung pada materi pokok balok di kelas VIII SMP Negeri 11 Padangsidimpuan. Rata-rata angket siswa pada kelas eksperimen lebih baik dibandingkan kelas kontrol yakni $4,15>3,48$. Selain itu dapat dilihat dari perolehan tes kemampuan berfikir kreatif matematika siswa, dimana nilai rata-rata kemampuan awal pada kelas eksperimen sebesar 63,92 dan kelas kontrol 61,80. Setelah mendapatkan perlakuan, nilai rata-rata kemampuan akhir siswa pada kelas eksperimen adalah 78,00 sedangkan pada kelas kontrol adalah 71,96.

\section{DAFTAR PUSTAKA}

Istarani. 2011. 58 Model-Model Pembelajaran Inovatif. Medan: Media Persada Mahmudi, Ali. 2010. Mengukur Kemampuan Berpikir Kreatif Matematis. Makalah: Universitas Negeri Yogyakarta (httpstaff.uny.ac.idsitesdefault filespenelitianAli\%20Mahmudi,\%20S.Pd,\%20M.Pd,\%20Dr.Makalah\%2014 \%20ALI\%20UNY\%20Yogya\%20for\%20KNM\%20UNIMA\%20__ M engukur\%20Kemampuan\%20Berpikir\%20Kreatif\%20_pdf) diakses pada tanggal 23 desember 2013

Ngalimun. 2012. Strategi dan Model Pembelajaran. Banjarmasin: Aswaja Pressindo Rusman. 2012. Model- Model Pembelajaran Mengembangkan Profesionalisme Guru. Jakarta: PT Rajagrafindo Persada

Slavin, Robert E. 2005. Cooperatif Learning Teori, Riset dan Praktik. Bandung: Nusa Media 